Volume: 11 Issue: 1 Year: 2014

\section{Mobbing in primary schools in the context of gender perspective $^{1}$}

\author{
Serap Karabacak Aşır ${ }^{2}$ \\ Gülden Akın ${ }^{3}$
}

İlköğretim okullarındaki y1ldirmaya (mobbing) toplumsal cinsiyet bağlamında bir bakış

\begin{abstract}
This study aims to determine the degree of mobbing (psychological violence) that primary schools teachers face with in the context of the gender variable. The study is carried out by using a Likert-type scale questionnaire answered by the participants. A 33-item questionnaire, consisting of 2 parts, is applied to 230 teachers, 115 females and 115 males, who work in public primary schools of Ministry of Education. The first part of the questionnaire consists of a form prepared by the scale of mobbing while the second part consists of a form in which the ideas of the participants about the effectiveness of in-service training for adults in the prevention of mobbing are asked. The study sample is composed of teachers who work in 4 primary schools in Mamak district of Ankara. The research is limited with variables such as gender, age, marital status, seniority and tenure. The obtained data are analyzed by considering gender context. According to the findings of research, mobbing is applied to female teachers more than male teachers in primary schools. Married female teachers working in primary schools who are between the ages of 21 to 30 are more exposed to mobbing. Female teachers
\end{abstract}

Özet

$\mathrm{Bu}$ araştırma, ilköğretim okullarında çalışan öğretmenlerin yıldırmaya uğrama düzeylerini toplumsal cinsiyet değişkeni bağlamında belirlemek amacıyla yapılmıştır. Araştırma, likert tipi ölçek kullanılarak hazırlanan anketin katilimcilar tarafindan cevaplanmasi ile gerçekleştirilmiştir. 33 maddelik 2 bölümden oluşan bu anket, Milli Eğitim Bakanlığı'na bağlı ilköğretim kurumlarında görev yapan 115'i kadın, 115'i erkek toplam 230 öğretmene uygulanmıştır. Anketin ilk bölümünde yıldırma ölçeği ile hazırlanmış bir form, ikinci bölümünde ise yldırmanın önlenmesinde yetişkinlere yönelik hizmet içi eğitim faaliyetlerinin etkililiği hakkında katılımcıların düşüncelerinin sorulduğu başka bir form bulunmaktadır. Araştırmanın çalışma grubunu Ankara'nın Mamak İlçesindeki 4 ilköğretim okulunda çalışan öğretmenler oluşturmaktadır. Araştırma cinsiyet, yaş, medeni durum, kıdem, kurumdaki görev süresi gibi değişkenlerle sınırlı tutulmuștur. Elde edilen veriler toplumsal cinsiyet bağlamı göz önünde bulundurularak analiz edilmiştir. Araştırma sonucu elde edilen bulgulara göre, ilköğretim kurumlarında yıldırma daha çok kadın öğretmenlere

\footnotetext{
1 A part of this study was presented in the "International Applied Education Congress", on 13-15 September, 2012 METU, Ankara/TURKEY.

2 Dr., Ministry of National Education, Ankara, novasera@yahoo.com

${ }^{3}$ Dr., Turkish National Police Academy, Faculty of Security Sciences, Mandatory and Practical Courses Head Office, Ankara. akingulden@gmail.com
} 
Karabacak Aşır, S., \& Akın, G. (2014). İlköğretim okullarındaki yıldırmaya (mobbing) toplumsal cinsiyet bağlamında bir bakıs.. International Journal of Human Sciences, 11(1), 584-602. doi: 10.14687/ijhs.v11i1.2655

who are experienced between 1 and 3 years are more exposed to mobbing compared to their colleagues. Besides, the mobbing rate decreases as the tenure increases. Participants think that administrators they work with should attend trainings on adult psychology and behaviors, yet they are not sure whether this training can change the behaviors of their administrators.

Keywords: Mobbing; teacher; psychological violence; gender; adult education

\section{(Extended English abstract is at the end of this} document) uygulanmaktadır. İlköğretim kurumlarında görev yapan 21-30 yaş arasındaki evli kadın ögretmenler daha fazla yıldırmaya maruz kalmaktadırlar. Meslek yılı 1-3 sene arasındaki kadın öğretmenler diğer meslektaşlarına oranla daha fazla yldırmaya maruz kalırken, kurumdaki görev süresi arttıkça yıldırmaya maruz kalma oranı azalmaktadır. Katılımcılar, birlikte çalıştıkları idarecilerin yetişkin psikolojisi ve davranışları konusunda eğitim almaları gerektiğini düşünürken, bu eğitimi alsalar da idarecilerinin davranışlarının değişebileceği konusunda kararsız kalmışlardır.

Anahtar kelimeler: Yıldırma; öğretmen; psikolojik şiddet; toplumsal cinsiyet; yetişkin eğitimi

\section{Giriş}

Yıldırma İngilizce bir kavramdır ve "mob" kökünden gelmektedir. Mob kanun dışı, şiddet uygulayan, düzensiz kalabalık veya çete olarak tanımlanırken, bu kökün fill biçimi olan yıldırma ise; psikolojik şiddet, kuşatma, taciz, rahatsız etme veya sıkıntı vermek anlamlarına gelmektedir (Oxford Advanced Learner's Dictionary, 2005). Yıldırma, ilk olarak on dokuzuncu yüzyılda yuvalarını korumak için saldırganın etrafında uçan kuşların davranışlarını betimlemek amacıyla biyologlar tarafindan İngilizce bir kavram olarak kullanılmıştır (Tınaz, 2006).

Dünyanın var oluşundan bu zamana kadarki süreçte yıldırma olgusu hep olmuştur, fakat isimlendirilmemiştir. Özellikle 20. yüzyıldan itibaren, sanayileşmenin hızlanması sonucu, çalışan sayısının ve çalışanlar arası rekabetin artması, çalışanların birbirlerini psikolojik olarak taciz etmeleri, güçlü olanın zayıf olanı ezmesi sonucu, Türkçe olarak da yıldırma ve "Psikolojik Şiddet" olgusunu ortaya çıkarmaktadır (Ekiz, 2010).

"Yıldırma üzerine araştırma yapanlar, bu olguyu tek bir sözcükle ifade etmek yerine, kavramın Türkçe karşılluğ olarak "iş yerinde psikolojik taciz", "işyerinde psikolojik-terör", "işyerinde psikolojik şiddet", "işyerinde duygusal taciz", "işyerinde moral taciz", "işyerinde manevi taciz", "işyerinde zorbalık", "yıldırma" ve "işyerinde yıldırmaya yönelik psikolojik saldırı" sözcüklerini kullanarak yaygınlaştırmıştır” (Çobanoğlu, 2005).

Tanımlardan da anlaşılacağı gibi yıldırma iş dünyası ile ilişkilendirilen bir kavramdır ve dünyanın hemen her yerindeki kamu ve özel sektör örgütlerinde yıldırma davranışlarının çalışanlarca birbirlerine uygulandığ kabul edilmektedir. 
Karabacak Aşır, S., \& Akın, G. (2014). İlköğretim okullarındaki yıldırmaya (mobbing) toplumsal cinsiyet bağlamında bir bakıs.. International Journal of Human Sciences, 11(1), 584-602. doi: 10.14687/ijhs.v11i1.2655

Yıldırma birçok araştırmada tanımlanmış olmakla birlikte, üzerinde tam olarak anlaşılmış ve ortak karara varılmış bir "yıldırma” tanımı yapılamamıştır. Bu durum işgörenlerin işyerlerinde karşı karşıya kaldıkları bu eylemlerin etkilerini ortaya çıkarmayı zorlaştırmaktadır (Yücetürk, 2003).

Yapılan tanımlara göre yıldırma; işyerinde örgütte çalışanlar arasında birbirlerine karşı uygulanan benzer tipte, sistematik ve uzun dönemli düşmanca ve saldırganca davranışlardır (Çobanoğlu, 2005).

Tutar’a (2004) göre; yıldırma, çalışanlara üstleri, astları veya kendileriyle eşit düzeyde olanlar tarafindan sistematik biçimde uygulanan her türlü kötü muamele, tehdit, şiddet, aşağılama davranışlarıdır.

Einarsen (1999) yıldırmayı; "İşyerindeki bir kişinin bir veya daha fazla meslektaşının veya üstlerinin uzun süre sistematik biçimde uygulanan saldırgan davranışlarına maruz kalması ve kendisini savunmasız hissedip, o ortamdan kaçmak istemesi olarak tanımlar. Bu tür bir davranış hedefi küçük düşürme ve damgalama eğilimi gösterir ve ciddi psikolojik travmaya neden olabilir”"

Davenport ve diğerleri (2003), yıldırmanın bir veya birkaç kişi tarafindan yapılabileceğine dikkat çekerek, yıldırmayl; "bir kişinin, diğer insanları kendi rızaları ile veya rızaları dışında başka bir kişiye karşı etrafında toplaması ve sürekli kötü niyetli hareketlerde bulunma, ima, alay ve karşısındakinin toplumsal itibarını düşürme gibi yollarla, saldırgan bir ortam yaratarak onu işten çıkarmaya zorlaması" olarak tanımlamaktadır.

Leymann 1984 yılında İsveç'te yıldırma davranışlarını tanımlarken bu davranışların bir tür iş yeri terörü olduğu vurgulamıştır. Bu terör bir ya da birkaç kişinin tek bir kişiye sistemli olarak yönettikleri etik dışı iletişim ve düşmanca davranışlardan oluşmaktadır (Leymann, 1996). Bu durum da örgütün verimliliğini etkileyecektir. Yıldırma sürecinin örgüte bir başka etkisi de işçilerin tazminat talepleri olacaktır. Ülkemizde henüz bu süreç yasalarda tanımlanmamış olmasına karşın bazı devletler, işle ilgili stresin neden olduğu fiziksel ve ruhsal hastalıklar için işçilerin tazminat talebini kabul etmiştir (Tutar, 2004).

Türkiye'de ise yıldırma sürecine ne akademik çevrelerin ne iş çevrelerinin ne de meslek örgütlerinin dikkati, henüz yeterli oranda çekilememiştir. 2005-2012 y1lları arasındaki akademik çalışmalar incelendiğinde; yıldırma ile ilgili 198 yüksek lisans ve doktora tez çalışması olduğu görülmüştür (www.yok.gov.tr/ulusaltezmerkezitaramasonuclari). Bu çalışmaların yalnızca 48 tanesi eğitim ve öğretim alanındaki yıldırma ile ilgilidir. Eğitim alanında gerçekleştirilen çalışmalarda; yöneticilerin uyguladığı yıldırma (Yıldırım, 2010), yöneticinin yönetim tarzından kaynaklanan yıldırma (Cengiz, 2010), öğretmenlerin yıldırma alg1ları (Ocak, 2008), ilköğretim okulu öğretmenlerinin eğitim örgütlerinde duygusal şiddete ilişkin görüşleri (Onbaş, 2007), öğretmenlerin 
Karabacak Aşır, S., \& Akın, G. (2014). İlköğretim okullarındaki yıldırmaya (mobbing) toplumsal cinsiyet bağlamında bir bakıs.. International Journal of Human Sciences, 11(1), 584-602. doi: 10.14687/ijhs.v11i1.2655

maruz kaldıkları yıldırma eylemlerinin tükenmişlikleri ile ilgisi (Mimaroğlu Bucuklar, 2009) gibi konuların ele alındığı görülmüştür.

Araştırmalardan da anlaşılabileceği gibi iş yaşamındaki yıldırma çeşitli boyutları ile ele alınmıştır. Ancak, değişen dünyada artık kadınların da iş hayatının çeşitli aşamalarında erkeklerle birlikte çalışması yıldırmanın toplumsal cinsiyet boyutunu akla getirmektedir. Toplumsal cinsiyet en yalın tanımı ile, bir toplumun cinsiyete atfettiği görev ve davranışlardır. Toplumsal cinsiyet biyolojik cinsiyetten farklı olarak toplumsal ve kültürel olarak belirlenen ve dolayısıyla içeriği toplumdan topluma olduğu kadar tarihsel olarak da değişebilen cinsiyet konumu ya da cins kimliğidir (Ökten, 2009). Kişilerden bu öğretilere ya da cins kimliğine uygun hareketler yani toplumsal cinsiyet rolleri sergilemeleri beklenir (Connell, 1998).

Toplumsal cinsiyet klişesi bağlamında kadından, ataerkil tahakküm ile doğru orantılı olarak erkeğin üstünlüğünü kabul etmesi beklenir. Bu üstünlüğü kabul ediş, biyolojik, ekonomik ve dinsel temellere dayandırılır (Tan, 1979). Sosyal hayatta erkek veya kadın olmanın anlamı, kişinin cinsiyeti ile belirlenen genel bir rolün yani cinsiyet rolünün toplumda canlandırılmasıdır. Cinsiyet rolünün uygulanması, sürecin öğrenilmesini gerektirir. Rolünü içselleştiren erkek veya kadından beklenenler, farklılık taşısa da her toplumda görülmektedir. Bu da toplumsal cinsiyetin kendini yeniden üreten, evrensel boyutunu vurgulamaktadır. Toplumsal cinsiyet alg1s1 ile birlikte sosyo-ekonomik değişkenler ve eğitim düzeyi, medeni durum, meslek gibi durumsal değişkenler ile mevcut siyasal yönelim; cinsiyet ayrımcılığının oluşmasına ve kalıcılaşmasına sebep olmaktadır (Güldü, Ersoy-Kart, 2009).

Cinsiyetlere yüklenen ve onlardan beklenen rolleri ifade eden toplumsal cinsiyet bağlamında evrensel olarak bütün toplumlarda çocuk bakımı, yetiştirilmesi gibi davranışlar kadından birincil görev olarak beklenmektedir. Kız çocukları, erken yaşlardan başlayarak bu rolü içselleştirmelerini sağlayan sosyalleşme süreçleri içinde bulunmaktadır. Yapılan araştırmalarda kendinden beklenenleri gerçekleştirirken eğitim, iş yaşamına katılma gibi kendilerini gerçekleştirme kanallarına yönelemeyen kadınlar arasında bu durumdan memnun olmayan ve durumlarını sorgulayanların olduğu bulgulanmıştır (Karabacak Aşır, 2011).

Kendine atfedilen roller nedeniyle ev dışında, gelir getirici etkinliklerde bulunamayan kadınların; değişen dünya konjüktürünün de etkisi ile artık erkekle birlikte çalışması zorunlu hale gelmiştir. Erkeklere ait görülen kamusal alanda kadınların boy göstermesiyle, toplumsal cinsiyet ile ilgili düşünce ve algıların yansımaları, iş hayatında da görünür hale gelmiştir. Erkek üstünlügüne dayalı ataerkil düzen ve bu düzenin toplumsal cinsiyet davranışlarını şekillendirmesi sonucunda, iş hayatında da kadınlardan kültürlenme süreçlerinde içselleştirdikleri rollere uygun davranmaları beklenmektedir. Beklentilerle iş hayatını gereklerinin örtüşmediği durumlarda, temelinde toplumsal 
Karabacak Aşır, S., \& Akın, G. (2014). İlköğretim okullarındaki yıldırmaya (mobbing) toplumsal cinsiyet bağlamında bir bakış. International Journal of Human Sciences, 11(1), 584-602. doi: 10.14687/ijhs.v11i1.2655

cinsiyet algılarının yattı̆̆ bir takım içsel ve kurumsal çatışmalar yaşanabilmektedir. Çatışmaların içeriği ve boyutu yıldırma araştırmalarına konu olmaktadır. Ülkemizde de araştırma konusuyla da ilgili olarak eğitim kurumlarında yaşanan yıldırmanın cinsiyet boyutuna ilişkin bazı çalışmalar yapılmıştır. Ancak bu çalışmalar toplumsal cinsiyet bağlamında değerlendirilmemiştir.

Eğitim alanında yıldırmanın çeşitli boyutları ile ilgili araştırmalar incelendiğinde; Ertürk (2005) tarafindan “Öğretmen ve Okul Yöneticilerinin Okul Ortamında Maruz Kaldıkları Yıldırma Eylemleri” adlı yüksek lisans tezinde; ilköğretim okullarında görev yapan öğretmen ve okul yöneticilerinin maruz kaldıkları yıldırma eylemlerinde, gruplar arasında en çok farkın gözetildiği değişkenlerin cinsiyet, görev ve yaş olduğu görülmüştür. Bu değişkenlerden elde edilen veriler; erkeklerin kadınlara göre; okul yöneticilerinin öğretmenlere göre ve araştırma kapsamında en üst yaş grubu olan 53 yaş üzeri grubun, diğer yaş gruplarına göre daha çok yıldırma eylemlerine maruz kaldıklarını ifade etmektedir.

Gökçe (2006) tarafindan "İşyerinde Yıldırma: Özel ve Resmi İlköğretim Okulu Öğretmen ve Yöneticileri Üzerine Yapılan Bir Araştırma” başlıklı doktora tezine göre; hem resmi hem de özel ilköğretim okullarında öğretmenler ve okul yöneticileri zaman zaman yıldırmaya uğramaktadırlar. Hem öğretmenlerin, hem de okul yöneticilerinin en sık karşılaştıkları yıldırma davranışları; "sözünün kesilmesi, yaptığ işlerin haksızca eleştirilmesi ve başarılarının küçümsenmesi” olduğu görülmüştür. Öğretmenlerin karşılaştıkları yıldırma davranışı, cinsiyete göre farklılık göstermemiştir.

Cemaloğlu ve Ertürk (2007) tarafından hazırlanan "Öğretmenlerin Maruz Kaldıkları Yıldırma Eylemlerinin Cinsiyet Yönünden İncelenmesi” adlı bir makalede; 2004-2005 eğitimöğretim yılında Ankara'nın dört merkez ilçesinde görevli 345 öğretmen ve 51 okul yöneticisi ile görüşülmüştür. Ulaşılan bulgularda, ilköğretim okullarında görev yapan erkek öğretmenlerin, "Kendini gösterme ve iletişim, sosyal ilişkiler, itibara saldırı, yaşam kalitesi ve mesleki durum” alt boyutlarında kadın öğretmenlere göre daha fazla yıldırmaya maruz kaldıkları, bu kişilere yönelik yıldırmaya başvuranların dörtte üçünün erkek, dörtte birinin ise kadın olduğu saptanmıştır.

Topkaya Sevinç (2011) çeşitli kurumlarda çalışan 20 kadının uğradığı yıldırma davranışları üzerinde çalışmıştır. Araştırmaların bulgularına göre, kadınlar erkeklerden daha çok yıldırmaya uğramaktadır. Erkek ve kadın çalışan sayısının eşit olduğu kurumlarda bile kadınların yıldırmaya daha çok maruz kaldıkları görülmüştür. Kadınlar yaşadıkları yıldırma sonucu çalıştıkları sektöre göre; tayin isteme veya emeklilik talep etme yolu ile iş yerinden uzaklaşmakta veya iş hayatından çıkmaktadırlar.

Yaşanan şiddet, iş hayatını bırakmaya kadar sonuçlanabilirken; yıldırma davranışlarının, uzun bir süre içinde ve sistematik olarak tekrarlanması tehlikeli bir silaha dönüşerek örnek bir yıldırma olayının ortaya çıkışını tetikler ve kasıtlı tacize dönüşür. $\mathrm{Bu}$ nedenle yıldırma sürecinin 
Karabacak Aşır, S., \& Akın, G. (2014). İlköğretim okullarındaki yıldırmaya (mobbing) toplumsal cinsiyet bağlamında bir bakış. International Journal of Human Sciences, 11(1), 584-602. doi: 10.14687/ijhs.v11i1.2655

anlaşılabilmesi için öncelikle işyerinde çalışanlar arasında görülen ve psikolojik tacize neden olan davranışların neler olduğunun ortaya koyulması gerekmektedir. (Tinaz, 2006).

Psikolojik tacize neden olan davranışların neler olduğunu belirleyebilmek için Keashly ve Jagatic (2003), yıldırma ile ilgili çeşitli araştırma sonuçlarını incelemiş ve iş yaşamında karşı karşıya kalınabilecek olan istismar (taciz) içerikli saldırganca davranışları; davranış kategorileri ve davranış örneklerini vererek Tablo 1. 'deki şekilde sınıflandırmıştır.

Tablo 1. İşyerinde İstismar ve Saldırgan Davranış Örnekleri

\begin{tabular}{|c|c|}
\hline $\begin{array}{l}\text { Davranış } \\
\text { Kategorisi }\end{array}$ & Davranış Örnekleri \\
\hline $\begin{array}{l}\text { Sözlü/ } \\
\text { Aktif/ }\end{array}$ & Onur kırıcı, hakaret içeren, aşağılayıcı veya küçültücü isimlerle çağırılmak \\
\hline Doğrudan & $\begin{array}{l}\text { Aşağılayıcı veya hakaret içeren şakalara konu edilmek } \\
\text { Zihinsel olarak küçümsenmek, aşağılanmak } \\
\text { Zalimce eleştirilmek, kusur bulunmak, yalnızken veya başkaları ile birlikteyken sözlü saldırılarda } \\
\text { bulunulmak; başkalarının önünde küçük düşürülmek } \\
\text { Küfür edilmek } \\
\text { Yalan söylenmek, aldatılmak } \\
\text { Bağırılmak } \\
\text { Konuşurken sözü kesilmek veya çalışması yarıda kesilmek } \\
\text { Kişisel yaşamını, inançlarını ve düşüncelerini değiştirmek yönünde baskıya maruz kalmak }\end{array}$ \\
\hline $\begin{array}{l}\text { Sözlü/ } \\
\text { Aktif/ }\end{array}$ & $\begin{array}{l}\text { Statü ile hava attlması ile karşı karşıya kalmak } \\
\text { Adil olmayan muamele görmek }\end{array}$ \\
\hline Dolayli & $\begin{array}{l}\text { Doğru olmayan suçlama ve dedikodulara konu olmak } \\
\text { Diğer kişilerin hedefteki kişiye sırtlarını dönmelerini sağlamaya çalışmak }\end{array}$ \\
\hline $\begin{array}{l}\text { Sözlü/ } \\
\text { Pasif/ } \\
\text { Doğrudan }\end{array}$ & Katkı ve yardımlarınızın geri çevrilmesi; sessiz muamele görmeniz \\
\hline $\begin{array}{l}\text { Sözlü/ } \\
\text { Pasif/ }\end{array}$ & Notlar birakılarak ve telefonla rahatsiz edilmek \\
\hline Dolayli & $\begin{array}{l}\text { Soruları yanıtsız bırakılmak, bilgi alamamak, danışmanlık görememek } \\
\text { Kasıtı olarak konuların dışında tutulmak } \\
\text { İhtiyaç duyduğu bilgilere ulaşmakta zorluk çıkarılmak }\end{array}$ \\
\hline $\begin{array}{l}\text { Fiziksel/ } \\
\text { Aktif/ }\end{array}$ & Ters, kızgin ya da öfkeli bakışlara maruz kalmak \\
\hline Dolayli & $\begin{array}{l}\text { Fiziksel olarak ani saldırılara maruz kalmak (Örneğin: Tekmelenmek, 1sirlmak, tokat atılmak) } \\
\text { Cinsel tacize uğramak } \\
\text { Irksal tacize uğramak }\end{array}$ \\
\hline $\begin{array}{l}\text { Fiziksel/ } \\
\text { Pasif / Dolaylı }\end{array}$ & $\begin{array}{l}\text { Eşyaları çalınmak veya eşyalarına zarar verilmek } \\
\text { Kasıtlı olarak aşırı iş yükü verilmek } \\
\text { İşine yarayacak kaynaklar kasıtlı olarak tüketilmek }\end{array}$ \\
\hline & Son teslim tarihi işe göre çok erken olan işler yaptırılmak, kaynak sıkıntısı çekilecek işler verilmek \\
\hline
\end{tabular}

Keashly ve Jagatic (2003)'in, işyerinde istismar ve saldırgan davranış örnekleri tablosu çeşitli şekillerdeki yıldırma davranışlarını sınıflandırarak, bu durumun belirlenmesini kolaylaştırmaktadır. 
Karabacak Aşır, S., \& Akın, G. (2014). İlköğretim okullarındaki yıldırmaya (mobbing) toplumsal cinsiyet bağlamında bir bakıs.. International Journal of Human Sciences, 11(1), 584-602. doi: 10.14687/ijhs.v11i1.2655

Yukarıdaki bilgilerden hareketle, sosyal hayatın her alanındaki tutum ve davranışları belirleyen ataerkil paradigma, kadından öncelikle erkek üstünlügünü kabul etmesini bekler. Bu üstünlüğün kabulünü ve devamlılı̆̆ını sağlamak üzere kurgulanan sistemin, bir parçası olan çalışma hayatında her kurumda görülebilen yıldırma davranışlarının, eğitim kurumlarındaki yansımalarının toplumsal cinsiyet boyutu olup olmadığı sorusu araştırmanın problemini oluşturmaktadır.

\subsection{Araştırmanın amacı ve önemi}

Araştırma öncesinde yapılan literatür çalışmasında, ilköğretim okullarında idareciler tarafindan öğretmenlere uygulanan yıldırmanın toplumsal cinsiyet boyutundaki boşluk saptanmıştır. Bu bağlamda araştırmanın amacı; ilköğretim okullarında idareciler tarafindan öğretmenlere uygulanan yıldırmayı araştırmak ve elde edilen verileri toplumsal cinsiyet boyutu ile analiz etmektir. Yapılan çalışma, ülkemizde okullarda idareciler tarafından gerçekleştirilen yıldırmanın derecesi konusunda bilgi vermesi bağlamında gereklidir. Ayrıca yıldırmanın önlenmesi için, katılımcıların yetişkin eğitimi etkinliklerinin etkililiği hakkındaki düşüncelerini ortaya koyması ve elde edilecek verilerin, gerçekleştirilecek yetişkin eğitimi faaliyetlerinin daha etkin sonuçlar vermesini sağlayabilecek olması açısından önemlidir.

Araştırmada Milli Eğitim Bakanlığına bağlı okullarda çalışan öğretmenlerin yıldırmaya uğrama durumlarının, demografik değişkenler karşısında özellikle toplumsal cinsiyet klişesi karşısında değişim gösterip göstermediğinin saptanabilmesi için aşağıdaki sorulara cevap aranmıştır:

1- Milli Eğitimi Bakanlığına bağlı İlköğretim devlet okulu öğretmeleri, yıldırmaya maruz kalma oranlarının cinsiyet değişkenine göre farklılık gösterdiğini düşünmekteler mi?

2- İlköğretim devlet okulu öğretmenlerinin, yıldırmaya maruz kalma oranları toplumsal cinsiyet bağlamında değerlendirildiğinde yaş değişkenine göre farklıllk göstermekte midir?

3- İlköğretim devlet okulu öğretmenlerinin, yıldırmaya maruz kalma oranları toplumsal cinsiyet bağlamında değerlendirildiğinde medeni durum değişkenine göre farklılık göstermekte midir?

4- İlköğretim devlet okulu öğretmenlerinin, yıldırmaya maruz kalma oranları toplumsal cinsiyet bağlamında değerlendirildiğinde meslek yılı değişkenine göre farkllılk göstermekte midir?

5- İlköğretim devlet okulu öğretmenlerinin, yıldırmaya maruz kalma oranları, toplumsal cinsiyet bağlamında değerlendirildiğinde aynı kurumda görev yapma süresi değişkenine göre farklıl1k göstermekte midir?

6- İlköğretim devlet okulu öğretmenleri, yıldırma uygulayan idarecilerin yetişkin psikolojisi ve davranışları eğitimi almasının gerektiğine inanıyorlar mı?

7- İlköğretim devlet okulu öğretmenleri, yıldırma uygulayan idarecilerin davranışlarının hizmetiçi yetişkin eğitimi faaliyetleri ile değişeceğine inanıyorlar mı? 
Karabacak Aşır, S., \& Akın, G. (2014). İlköğretim okullarındaki yıldırmaya (mobbing) toplumsal cinsiyet bağlamında bir bakiş. International Journal of Human Sciences, 11(1), 584-602. doi: 10.14687/ijhs.v11i1.2655

\subsection{Araştırmanın Sinırlılıkları}

1- Araştırma 2011-2012 eğitim öğretim yllında Milli Eğitim Bakanllğına bağlı dört devlet ilköğretim okuluyla;

2- Araştırma çalışmanın yapıldığı okullardaki 230 öğretmen ile;

3- Değerlendirme ölçeğindeki sorularla sinırlıdır.

\section{Yöntem}

\subsection{Araştırma Modeli}

$\mathrm{Bu}$ araştırmada, ilköğretim idarecilerinin öğretmenlere uyguladıkları yıldırmanın toplumsal cinsiyet boyutu ile ilgili, öğretmenlerin görüşlerinin değerlendirilmesi amaciyla betimsel yöntem kullanılmıştır. Betimsel tarama modelinde, olaylar, objeler, varlıklar, kurumlar, gruplar ve çeşitli alanların ne olduğu betimlenmeye çalışılır. Survey adı da verilen bu çalışmalar, çok sayıda obje ya da denek üzerinde ve belirli bir zaman kesiti içinde yapılır. Böylelikle, obje veya denekleri iyi anlayabilme, gruplayabilme ve aralarındaki ilişkiyi daha iyi saptayabilme olanağı sağlanmış olur (Kaptan, 1993).

\subsection{Veri Toplama Araçları}

Demografik verileri toplamak için kişisel bilgi formu ve yıldırma belirleme ölçeği olarak kullanılmak için hazırlanan anket formu veri toplama araçları olarak belirlenmiştir.

Anketin birinci bölümü olan yıldırma belirleme ölçeği; Keashly ve Jagatic (2003)'in oluşturduğu, yıldırma ile ilgili olarak iş yaşamında karşı karşıya kalınabilecek olan istismar (taciz) içeren ve saldırgan davranışlar tablosundaki maddeler kullanılarak hazırlanmıştır. Anketin ikinci bölümündeki üç cümle ile yıldırmayı önlemek amacıyla düzenlenecek hizmet içi eğitimlerin gerekliliği hakkında katılımcıların düşünceleri sorulmuştur.

\subsection{Verilerin Analizi}

Araştırmada, anketteki cümlelerin, beş seçenekli cevap tablosundan birinin seçilmesiyle yanıtlanması amaçlanmıştır. Verilerin değerlendirilmesinde aşağıdaki aralık tablosu kullanılmıştır.

Tablo 2. Puan Aralikları

\begin{tabular}{lcc}
\hline Seçenekler & Verilen Puanlar & Puan Aralığ1 \\
\hline Kesinlikle Katılmıorum & 1 & $1,00-1,79$ \\
Katılmıyorum & 2 & $1,80-2,59$ \\
Kararsizım & 3 & $2,60-3,39$ \\
Katıliyorum & 4 & $3,40-4,19$ \\
Kesinlikle Kattlyorum & 5 & $4,20-5,00$ \\
\hline
\end{tabular}

Öncelikle taslak olarak hazırlanan ve 38 cümleden oluşan bir anket 40 öğretmene uygulanmış ve sonuçlar bir uzmanın da görüşleri alınarak değerlendirilmiştir. Bu aşamadan sonra, anket üstünde gerekli düzenlemeler yapılmış ve ölçeğe son şekli verilerek 33 cümleden oluşan ankete dönüştürülmüştür. Ardından, araştırmanın örneklemini oluşturan 230 öğretmene anket 
Karabacak Aşır, S., \& Akın, G. (2014). İlköğretim okullarındaki yıldırmaya (mobbing) toplumsal cinsiyet bağlamında bir bakiş. International Journal of Human Sciences, 11(1), 584-602. doi: 10.14687/ijhs.v11i1.2655

uygulanmış ve elde edilen veriler; frekans ve aritmetik ortalama değerleri kullanılarak çözümlenmiştir.

\section{4. Çalı̧̧ma Grubu}

Araştırma Ankara ili Mamak ilçesi sınırlarında gerçekleştirilmiştir. Mamak ilçesi araştırmacılardan birinin bu ilçede görev yapıyor olması ve katılımcılara ulaşma kolaylığı sebebiyle tercih edilmiştir. Ön çalışma araştırmacının görev yaptı̆̆ı kurumda yapılmıştır. Sonrasında Mamak İlçe Milli Eğitim Müdürlüğü bölgesinde, ulaşımın kolay olduğu ilköğretim okullarından birine gidilerek araştırmanın çalışma grubu daraltılmıştır. Her gidilen ilköğretim okulunun yönlendirmesi ile başka bir okula gidilmiştir. Kartopu veya zincirleme örnekleme de denilen bu yöntemle, süreç ilerledikçe elde edilen isimler veya durumlar tıpkı kartopu gibi büyüyerek çalışma grubu oluşturulmuştur (Yıldırım, Şimşek 2006). Araştırmanın çalışma grubunu, 2011-2012 eğitim-öğretim yıllında Ankara ili Mamak ilçesinde öğretmenlik görevine devam eden 4 ilköğretim okulunda görev yapan 230 öğretmen oluşturmaktadır.

\section{Bulgular ve Yorumlar}

İlköğretim okullarındaki 115 kadın, 115 erkek öğretmenin cümlelerle verdiği yanıtlardan yola çıkılarak elde edilen verilerin frekans, aritmetik ortalama ve puan aralığı değerlerine ilişkin bulgular alt başlıklar ve tablolar halinde gösterilmiştir.

\section{1. İzin Talebi Değişkenine Göre Yıldırma}

İlköğretimde görev yapanların izin talebi değişkenine göre yıldırma algısı hakkında Tablo 3’ teki bulgulara ulaşılmıştır.

Tablo 3. Hastalık İzni Kaynaklı Yıldırma

\begin{tabular}{|c|c|c|c|c|}
\hline \multirow[t]{2}{*}{ Soru Numarası ve İfadeler } & \multicolumn{2}{|r|}{ Erkek } & \multicolumn{2}{|r|}{ Kadın } \\
\hline & $\bar{X}$ & $\begin{array}{l}\text { Puan Aralı̆̆1 } \\
\text { (İfade İle) }\end{array}$ & $\bar{X}$ & $\begin{array}{l}\text { Puan Aralığ1 } \\
\text { (Iffade İle) }\end{array}$ \\
\hline $\begin{array}{l}\text { 14. İdarecilerim kanunen hakkım olan hastalık izni gibi bazı } \\
\text { şeyleri talep etmemem için bana baskı yapar. }\end{array}$ & 1,95 & Katilmiyorum & 4,35 & $\begin{array}{l}\text { Kesinlikle } \\
\text { Katulyyorum }\end{array}$ \\
\hline
\end{tabular}

Kadınlar, toplumun kendilerinden beklediği davranışlarla iş yaşamının gerektirdiği davranışları çatışmayacak şekilde sergilemekte zaman zaman zorlanabilmekte ve kendilerinden beklenenleri yerine getiremediklerinde yıldırmaya uğrayabilmektedirler. Yapılan araştırmada soru kâğıdındaki 14. cümlede; erkek öğretmenler idarecilerin hastalık iznini almalarını zorlaştırmadığını belirtirken; kadın öğretmenler idarecilerin izin almalarını zorlaştırdığını ifade etmişlerdir. Burada kadın öğretmenlerin erkek öğretmenlere oranla daha sık izin almalarının etkili olduğu söylenebilir. Hastalık izni sadece kişinin kendi hastalığında kullanılmamaktadır. Aile yakınları ya da çocukları hasta olan öğretmenler de bu izinden faydalanabilmektedir. Toplumda çocuk ve hasta bakımı kadından beklenen bir davranış olduğundan çocuğu ya da ailesinden biri rahatsızlandığında kadın 
Karabacak Aşır, S., \& Akın, G. (2014). İlköğretim okullarındaki yıldırmaya (mobbing) toplumsal cinsiyet bağlamında bir bakıs.. International Journal of Human Sciences, 11(1), 584-602. doi: 10.14687/ijhs.v11i1.2655

öğretmenler daha sık izin almak zorunda kalabilir. S1k izin alma mecburiyeti de, yasalarla tanımlanmış süreler dâhilinde olsa da idarecilerce hoş karşılanmayabilir.

Erkek öğretmenlerin; "İdareciler kanunen hakkım olan hastalık izni gibi bazı şeyleri talep etmemem için baskı yaparlar." cümlesinde cevaplar 1,95 ile 'Katılmıyorum' puan aralığına karşılık gelirken kadın öğretmenlerin cevapları 4,35 ile 'Kesinlikle Katılıyorum' puan aralığına karşıllk gelmektedir. Tabloda da anlaşılacağı gibi katılımcılar aynı durum için farklı puan aralıklarına karşıllk gelen cevaplar vermişlerdir. Bu durumda hastalık izni alan kadın öğretmenlere karşı, idarecilerin davranışlarının yıldırma içerdiği sonucuna varılabilir.

\subsection{Adil Muamele Değişkenine Göre Yıldırma}

İlköğretim okulunda çalışan öğretmenlerin, karşı cinsle karşılaştırıldığında idarecilerden adil muamele görüp görmedikleri hakkındaki düşünceleri ile ilgili bulgular Tablo 4’te yer almaktadır.

Tablo 4. Adil Muamele ile İlgili Yıldırma

\begin{tabular}{|c|c|c|c|c|}
\hline \multirow[t]{2}{*}{ Soru Numarası ve İfadeler } & \multicolumn{2}{|r|}{ Erkek } & \multicolumn{2}{|r|}{ Kadın } \\
\hline & $\bar{X}$ & $\begin{array}{l}\text { Puan Aralığ1 } \\
\text { (İfade İle) }\end{array}$ & $\bar{X}$ & $\begin{array}{c}\text { Puan Aralığ1 } \\
\text { (Iffade İle) }\end{array}$ \\
\hline $\begin{array}{l}\text { 15. İdarecilerimden işle ilgili konularda adil olmayan muamele } \\
\text { görürüm. }\end{array}$ & 3,25 & Kararsizım & 3,45 & Katuliyorum \\
\hline
\end{tabular}

Soru kâğıdında 15. numarada yer alan 'İdarecilerimden işle ilgili konularda adil olmayan muamele görürüm.' cümlesinde; erkek öğretmenler 3,25 puanla 'Kararsızım' seçeneğine karş1llk gelen şekilde cevaplama yapmışken, kadın öğretmenler 3,45 puanla 'Katıllyorum' seçeneğine karş1lık gelen şekilde cevaplama yapmışlardır. Okullarda, ek ders ücreti karşıllı̆̆1 ders dışı etkinlikler yapılmaktadır. Bu etkinliklerde görev alacak öğretmenlerin seçiminde idarecilerin inisiyatif kullanmalarını gerektiren durumlar bulunabilir. Erkek öğretmenlerin mesai saatleri dışında okulda uzun süreler daha rahat kalabileceği düşüncesi idarecilerin bu gibi durumlarda erkek öğretmenleri tercih etmesine neden olabilir. İdarecilerin bu cinsiyetçi yaklaşımları, kadının ev dışı işlerde çalışmasının temel koşullunun aile- içi görevlerini aksatmayacak şekilde çalışması (Tan,1979) olduğu fikrini içselleştirdikleri şekilde yorumlanabilir. Kadın öğretmenlere danışılmadan erkek öğretmenlere okul dışı etkinlik görevlerinin verilmesi, yaptıkları etkinlik için ek ders ücreti alan erkek öğretmenlerle kadın öğretmenler arasında bir gelir adaletsizliğine de yol açabilmektedir.

Görev dağılımı yapılırken, il ya da ilçe komisyonlarındaki toplantılar için erkek öğretmenlere; okuldaki kermes ya da yllsonu sergisi gibi etkinliklerde ise kadın öğretmenlere görev verilmesi idarecilerin cinsiyetçi yaklaşımlarına başka bir örnek olarak gösterilebilir. Cinsiyet temelli görev dağılımları, kadın öğretmenlerin iş ile ilgili konularda hakkaniyet sınırları içinde davranış görmedikleri ve yıldırmaya maruz kaldıkları sonucuna varmalarına neden olabilmektedir. Erkek öğretmenler adil davranış konusunda 3,25 ile 'Kararsızım' puan aralığını seçerken, kadın öğretmenlerin cevabı ise 'Katıllıorum' puan aralığına karşılık gelmektedir. 
Karabacak Aşır, S., \& Akın, G. (2014). İlköğretim okullarındaki yıldırmaya (mobbing) toplumsal cinsiyet bağlamında bir bakıs.. International Journal of Human Sciences, 11(1), 584-602. doi: 10.14687/ijhs.v11i1.2655

\subsection{Cinsiyet Değişkenine Göre Yıldırma}

"İlköğretim devlet okulu öğretmenlerinin ylldırmaya maruz kalma durumları toplumsal cinsiyet bağlamında değerlendirildiğinde cinsiyet değişkenine göre farkll1ık göstermekte midir?" soru cümlesi bağlamında aşağıdaki bulgulara ulaşılmışır.

Tablo 5. Cinsiyet Değişkenine Göre Yıldırma

\begin{tabular}{|c|c|c|c|c|}
\hline \multirow[t]{2}{*}{ Soru Numarası ve İfadeler } & \multicolumn{2}{|r|}{ Erkek } & \multicolumn{2}{|r|}{ Kadın } \\
\hline & $\bar{X}$ & $\begin{array}{l}\text { Puan Aralı̆̆1 } \\
\text { (İfade İle) }\end{array}$ & $\bar{X}$ & $\begin{array}{l}\text { Puan Aralığ } \\
\text { (İfade İle) }\end{array}$ \\
\hline $\begin{array}{l}\text { 18. İdarecilerim tarafından cinsiyetim nedeniyle ayrımcıllı̆a } \\
\text { uğrarım. }\end{array}$ & 1,55 & $\begin{array}{l}\text { Kesinlikle } \\
\text { Katulmiyorum }\end{array}$ & 4,25 & $\begin{array}{l}\text { Kesinlikle } \\
\text { Katuliyorum }\end{array}$ \\
\hline
\end{tabular}

Sosyal hayatta toplumsal cinsiyet rolleri, kadınlığın ve erkekliğin biyolojik tanımlarından farklı şekilde toplumların dünya görüşü, inanış, ihtiyaç ve beklentileri temel alınarak kurgulanır. Roller ise eril tahakkümün belirlediği ve sonucunda cinsiyet ayrımcllı̆̆ını ortaya çıkartan ve bu bağlamda sosyal alanı kamusal ve özel alan olarak kurgulayıp erkeğe kamusal alanı kadına ise özel alanı uygun gören bir yaklaşımı benimser (Sankır, 2010). Sosyalleşme süreci ve eğitim aracıllğıyla, yeniden üretilen ataerki üstünlüğü ve dolayısıyla cinsiyet ayrımcıllğı, erkeğin kadına göre kendini daha üstün konumlandırması ile kendini göstermektedir. Ataerkinin biçimlendirmesini yaptığ1 kamusal alanda bulunan her türlü kurumda paradigma erkek üstünlüğünü pekiştirecek şekilde düzenlenirken kadınlara düşen bu paradigmanın işlerliğini sağlamaktır. Kamusal alanın en yaygın kurumlarından olan okullarda da bu hâkim düşünce sisteminin yansımaları görülmektedir. İdarecilerin; erkeklere atfedilen atılganlık, girişkenlik gibi özellikleri içselleştirmeleri onların; birtakım görevler için, seminer verme, idare düzeyinde okulu temsil etme v.b, erkek öğretmenlerin daha uygun olduğu düşüncesini içselleştirmelerine yol açabilmektedir. Kadınların ise sosyalleşme sürecinde pasif ve bağımlı olarak yetiştirilmeleri, kendilerine atfedilen duygusal olma gibi özellikler nedeniyle kariyerlerine olumlu katkıda bulunacak etkinliklere katılmaları idareciler tarafindan güçleștirilebilmektedir. Kadınlar, erkeklere uygun görülen etkinlikleri gerçekleştirmek istediklerinde, rol bağlamında çatışma yaşanabilmektedir. $\mathrm{Bu}$ çatışma bir bireyin karşı grubun etkinliğini gerçekleştirmeye kalkması ile ortaya çıkar (Oglesby ve Hill, 1993). Çatışma sürecinde yaşananlar ise kadınlar tarafından yıldırma olarak algılanabilmektedir. Yapılan çalışmalarda da kadınların toplumsal cinsiyetinin iş hayatında yıldırmaya uğramalarında etkili olduğu bulgulanmıştır (Topkaya Sevinç, 2011).

Tablo 5'te verilen ve ankette 18 numarada yer alan; "İdarecilerim tarafindan cinsiyetim nedeniyle ayrımcllığa uğrarım." cümlesine erkek öğretmenlerin en çok işaretledikleri 'Kesinlikle Katılmıyorum' seçeneği 1,55 puan almışken, kadın öğretmenlerin en çok işaretledikleri 'Kesinlikle Katılıyorum' seçeneği 4,35 puan almıştır. Bu bağlamda, idarecilerin kadın ve erkek öğretmenlere aynı durum için farklı davranışlar sergileyerek yıldırmaya neden oldukları söylenebilir. 
Karabacak Aşır, S., \& Akın, G. (2014). İlköğretim okullarındaki yıldırmaya (mobbing) toplumsal cinsiyet bağlamında bir bakıs.. International Journal of Human Sciences, 11(1), 584-602. doi: 10.14687/ijhs.v11i1.2655

\subsection{Yaş Değişkenine Göre Yıldırma}

"İlköğretim okulu öğretmenlerinin yıldırmaya maruz kalma süreçleri, toplumsal cinsiyet bağlamında değerlendirildiğinde yaş değişkenine göre farklılık göstermekte midir?" sorusunun cevabı aşağıdaki tabloda gösterilmiştir.

Tablo 6. Yaş Değişkenine Göre Yıldırma

\begin{tabular}{|c|c|c|c|c|}
\hline \multirow[t]{2}{*}{ Yaş değişkenine göre } & \multicolumn{2}{|r|}{ Erkek } & \multicolumn{2}{|r|}{ Kadın } \\
\hline & $\bar{X}$ & Puan Aralığ1 (İfade İle) & $\bar{X}$ & Puan Aralığı (İfade İle) \\
\hline $21-30$ yaş & 2,90 & Kararsızım & 4,32 & Kesinlikle Katulyyorum \\
\hline $31-40$ yaş & 2,30 & Katilmiyorum & 3,87 & Katuliyorum \\
\hline $41-50$ yaş & 2,05 & Katilmiyorum & 3,25 & Kararsizım \\
\hline 50 yaş ve üstü & 1,81 & Katilmiyorum & 2,40 & Katilmiyorum \\
\hline
\end{tabular}

Tablo 6’ya göre, katılımcıların yaş aralığına bakıldığında kadın katılımcıların 21-30 yaş arasında olanların diğer yaş gruplarına ve erkek katılımcılara oranla daha çok yıldırmaya uğradıklarını düşündükleri belirlenmiştir. Yaş ilerledikçe yıldırmaya uğradığını belirtme durumunun azaldığ1 görülmüştür. Erkek katılımcıların ise 21-30 yaş aralığından itibaren değerlendirildiğinde yıldırmaya düşük düzeyde maruz kaldıklarını düşündükleri anlaşılmıştır. Bu verilerden yola çıkarak genç yaştaki kadın öğretmenlerin aynı yaş grubundaki erkek öğretmenlerden daha fazla yıldırmaya uğradıkları söylenebilir. Kadınlar, yaşları ilerledikçe yıldırmaya daha az uğradıklarını ifade etmiş olsalar da bu alg1 değişmesinden de kaynaklanabilmektedir. Genç öğretmenler yaşadıklarını yıldırma olarak tanımlarken yaşı ilerleyenler; meslek yaşantısının bir parçası, iş hayatının getirdiği olumsuzluklar olarak niteleyebilmektedirler. İlerleyen yaşla birlikte öğretmenler bu rahatsız edici durumla başa çıkabilmek için kabullenme, normal sayma davranışları içine girmiş olabilirler. Elde edilen verilerden yola çıkarak ilköğretim okullarında, erkek öğretmenlerle aynı yaş aralığındaki kadın öğretmenlerin daha çok yıldırmaya maruz kaldıkları bulgulanmıştır.

\subsection{Medeni Durum Değişkenine Göre Yıldırma}

"İlköğretim devlet okulu öğretmenlerinin yıldırmaya maruz kalma durumları toplumsal cinsiyet bağlamında değerlendirildiğinde medeni durum değişkenine göre bir farkllılı göstermekte midir?" soru cümlesi bağlamında aşağıdaki bulgular elde edilmiştir.

Tablo 7. Medeni Durum Değişkenine Göre Yıldırma

\begin{tabular}{|c|c|c|c|c|}
\hline \multirow[t]{2}{*}{ Medeni Duruma Göre } & \multicolumn{2}{|r|}{ Erkek } & \multicolumn{2}{|r|}{ Kadın } \\
\hline & $\bar{X}$ & $\begin{array}{l}\text { Puan Aralığ1 (İfade } \\
\text { İle) }\end{array}$ & $\bar{X}$ & $\begin{array}{c}\text { Puan Aralığ1 } \\
\text { (İfade İle) }\end{array}$ \\
\hline Evli & 1,92 & Katilmiyorum & 3,49 & Katillyorum \\
\hline Bekar & 1,95 & Katulmiyorum & 3,04 & Kararsızım \\
\hline
\end{tabular}


Karabacak Aşır, S., \& Akın, G. (2014). İlköğretim okullarındaki yıldırmaya (mobbing) toplumsal cinsiyet bağlamında bir bakıs.. International Journal of Human Sciences, 11(1), 584-602. doi: 10.14687/ijhs.v11i1.2655

Tablo 7'den anlaşılabileceği gibi medeni durum değişkeni bağlamında evli kadın öğretmenler, gerek bekar ya da evli erkek öğretmenlerden; gerekse bekar kadın öğretmenlerden daha çok yıldırmaya uğradıklarını belirtmişlerdir. Bu durumun nedeni evlendikten sonra ev ve sonrasında çocuklar nedeniyle sorumlulukları artan kadınların, iş yaşantısında idarecilerin beklediği performansı gösterememesi olabilir. Özellikle çocuğu olan kadınların çocukları ile ilgili her durumda hastalık v.b izin almak zorunda kalmaları onların yıldırmaya uğrama oranlarını arttırabilmektedir. Erkek evlense de toplumun kendinden beklediği davranışlar iş yaşantısı ile çelişmediği gibi evlenmenin olumlu etkisi kariyerlerinde başarılı olmalarını da sağlayabilmektedir. Oysa toplumda kadından erkeklere oranla mesleki başarı beklentisi azdır. Kadın için başarının ölçütü temel ve sonul bir biçimde başarılı bir evlilik yapabilmesiyken erkek için başarı iş ve meslek yaşamındaki konuma ve koşullarına göre tanımlanmaktadır (Tan, 1979). Kendinden kariyerinde ilerleme beklenmeyen evli kadınlar bu soru cümlesi ile idarecilerinin yıldırma davranışlarına daha çok maruz kaldıklarını düşündüklerini ifade etmiştir.

\subsection{Mesleki Kıdem Değişkenine Göre Yıldırma}

İlköğretim okulu öğretmenlerinin yıldırmaya maruz kalma oranlarının toplumsal cinsiyet bağlamında, meslek yılı değişkenine göre farkllık gösterip göstermediği Tablo 8'de gösterilmiştir.

Tablo 8. Mesleki Kıdem Değișkenine Göre Yıldırma

\begin{tabular}{|c|c|c|c|c|}
\hline \multirow[t]{2}{*}{ Mesleki Kıdeme Göre } & \multicolumn{2}{|r|}{ Erkek } & \multicolumn{2}{|r|}{ Kadın } \\
\hline & $\bar{X}$ & $\begin{array}{c}\text { Puan Aralığ1 } \\
\text { (Iffade İle) }\end{array}$ & $\bar{X}$ & Puan Aralığ1 (İfade İle) \\
\hline 1- 4 yll & 3,01 & Karasizım & 4,54 & Kesinlikle Katiliyorum \\
\hline $\begin{array}{l}5-8 \mathrm{yll} \\
9-12 \mathrm{yll}\end{array}$ & $\begin{array}{l}2,11 \\
1,98\end{array}$ & $\begin{array}{l}\text { Katilmiyorum } \\
\text { Katulmiyorum }\end{array}$ & $\begin{array}{l}3,87 \\
3,05\end{array}$ & $\begin{array}{l}\text { Kattlyorum } \\
\text { Kararsizım }\end{array}$ \\
\hline 13 ve üstü & 1,93 & Katilmiyorum & 2,23 & Katilmiyorum \\
\hline
\end{tabular}

Tablo 8'e göre, meslek yılı değişkenine bakıldığında 1-3 arasında olan kadın öğretmenler, aynı meslek yılı aralı̆̆ında bulunan erkek öğretmenlerden daha fazla yıldırmaya uğradıklarını düşünmektedir. Erkek öğretmenlerin ise bu yöndeki algısı düşük düzeyde olmuştur. Kadın öğretmenler mesleklerinin ilk ylllarında mesleki bilgi ve mevzuat gibi, alan bilgilerindeki eksikliklerin de etkisi ile yıldırmaya uğrayabilmektedirler. Eksiklerini tamamlamak için gerekli olan hizmet içi eğitimlere ise özellikle evli ve çocukluların katılmasında güçlükler yaşanmaktadır. Kadına atfedilen birincil görevler arasında çocukları ve evi ile ilgili sorumlulukları yerine getirmesi bulunduğundan, kadınlar mesleki ve kişisel gelişimlerine katkıda bulunacak etkinlikler zaman ayıramamaktadır. Kadın öğretmenler de erkek öğretmenlerle eşit düzeyde eğitim aldıkları halde, toplumsal cinsiyet temelli rol beklentileri bağlamında, aldıkları eğitimin onları iyi eş ve iyi bir anne olmaya hazırlayacak eğitim olması gerektiği konusunda bir görüş birliği vardır (Tan, 1979). Kendilerinden bir meslek sahibi olmaları ya da mesleki anlamda gelişme istenmemektedir. Durum böyleyken kadın öğretmenlerin 
Karabacak Aşır, S., \& Akın, G. (2014). İlköğretim okullarındaki yıldırmaya (mobbing) toplumsal cinsiyet bağlamında bir bakıs.. International Journal of Human Sciences, 11(1), 584-602. doi: 10.14687/ijhs.v11i1.2655

mesleki ilerlemeye istek duymaları bile beklenmeyebilir. Erkek öğretmenler ise kariyer gelişimlerini tamamlamak için ihtiyaç duydukları eğitimlere; daha kolay katılabilirler. Çünkü kendilerinden beklenen, zamanlarını gelir getirici işle ile ilgili konulara ayırmalarıdır.

Kadın öğretmenlerin, tecrübe kazandıkça yıldırma algılarının azalma gösterdiği bulgulanmıştır. Bunun nedenler arasında mesleki gereklilikler anlamında tecrübe kazanmaları bulunabilmektedir. Ayrıca çocuklarının büyümesi ve onlarla ilgili direkt bakım isteyen durumların azalması sayesinde kariyer gelişimine odaklandıkları söylenebilir.

\subsection{Aynı Kurumda Görev Yapma Süresi Değişkenine Göre Yıldırma}

İlköğretim devlet okulu öğretmenlerinin yıldırmaya maruz kalma oranlarının toplumsal cinsiyet bağlamında, aynı kurumda görev yapma süresi değişkenine göre bir farklılık gösterip göstermediği aşağıda yer alan Tablo 9'da gösterilmektedir.

Tablo 9. Aynı Kurumda Görev Süresine Göre Yıldırma

\begin{tabular}{|c|c|c|c|c|}
\hline \multirow{2}{*}{$\begin{array}{l}\text { A. Aynı Kurumda Görev } \\
\text { Yapma Süresine Göre }\end{array}$} & \multicolumn{2}{|r|}{ Erkek } & \multicolumn{2}{|r|}{ Kadın } \\
\hline & $X$ & $\begin{array}{l}\text { Puan Aralığ1 } \\
\text { (Iffade İle) }\end{array}$ & $X$ & $\begin{array}{c}\text { Puan Aralığ1 } \\
\text { (İfade İle) }\end{array}$ \\
\hline $1-3 \mathrm{yll}$ & 3,20 & Kararsizım & 4,40 & $\begin{array}{l}\text { Kesinlikle } \\
\text { Katiliyorum }\end{array}$ \\
\hline $\begin{array}{l}4-6 \mathrm{yll} \\
7-9 \mathrm{yll}\end{array}$ & $\begin{array}{l}2,09 \\
1,95\end{array}$ & $\begin{array}{l}\text { Katilmiyorum } \\
\text { Katilmiyorum }\end{array}$ & $\begin{array}{l}3,73 \\
3,05\end{array}$ & $\begin{array}{l}\text { Katuliyorum } \\
\text { Kararsızım }\end{array}$ \\
\hline 9 ve üstü & 1,80 & Katulmiyorum & 2,18 & Katilmiyorum \\
\hline
\end{tabular}

Tablo 9'a göre, kurumdaki görev süresi değisskenine göre değerlendiğinde, erkek öğretmenlerin yıldırma algısı düşük düzeyde kalırken, kadın öğretmenlerin kurumda görev almaya başladıkları ilk yıllarda daha fazla yıldırmaya uğradıkları, kurumdaki görev süresi 1-3 yılın üzerine çıktıkça yıldırmaya uğrama algılarının azaldığı görülmüştür. Alg1 değişmesinin sebebi idarecilerin davranışlarına alışılması olabileceği gibi, kuruma yıldırma uygulamayan yeni bir idarecinin gelmesi de olabilir. Bunun yanında, idarecinin saptanabiliyorsa yıldırmaya neden olan davranışlarının öğrenilip öğretmenlerin ona göre davranmaları da kurumda görev yapma süresi arttıkça yıldırmaya daha az maruz kalınmasına yol açabilir. Elde edilen verilere göre, aynı kurumda görev yapan erkek öğretmenlerin görev sürelerinin başında da yıldırmaya daha az uğradıklarını ifade ettikleri görülürken, kadın öğretmenlerde bu durum görev süresi arttıkça azalmaktadır.

\subsection{Yıldırmanın Önlenmesinde Hizmet İçi Eğitim Faaliyetleri}

"İlköğretim devlet okulu öğretmenleri, yıldırma uygulayan idarecilerin davranışlarının hizmet içi yetişkin eğitimi faaliyetleri ile ya da iş üstünde eğitim faaliyetleri ile değişeceğine inanıyorlar mı?" cümlesine verilen cevaplar 10 numaralı tabloda gösterilmiştir. 
Karabacak Aşır, S., \& Akın, G. (2014). İlköğretim okullarındaki yıldırmaya (mobbing) toplumsal cinsiyet bağlamında bir bakiş. International Journal of Human Sciences, 11(1), 584-602. doi: 10.14687/ijhs.v11i1.2655

Tablo 10. Yıldırmanın Önlenmesinde Hizmet İçi Eğitim Faaliyetleri

\begin{tabular}{|c|c|c|c|c|}
\hline \multirow[t]{2}{*}{ Soru Numarası ve İfadeler } & \multicolumn{2}{|r|}{ Erkek } & \multicolumn{2}{|r|}{ Kadın } \\
\hline & $\bar{X}$ & $\begin{array}{l}\text { Puan Aralı̆g } \\
\text { (İfade İle) }\end{array}$ & $\bar{X}$ & $\begin{array}{l}\text { Puan Aralı̆̆1 } \\
\text { (Iffade İle) }\end{array}$ \\
\hline $\begin{array}{l}\text { 31. İdarecilerimin davranışlarının hizmet içi yetişkin eğitimi } \\
\text { faaliyetleri ile değişebileceğine inanıyorum. }\end{array}$ & 2,85 & Kararsızım & 2,70 & Karars1zım \\
\hline $\begin{array}{l}32 \text { İdarecilerimin davranışlarının iş üstünde eğitimle } \\
\text { değişebileceğine inanıyorum. }\end{array}$ & 3,30 & Kararsizim & 3,30 & Kararsizım \\
\hline $\begin{array}{l}\text { 33. İdarecilerimin yetişkin psikolojisi ve davranışlanı eğitimini } \\
\text { almasının gerekliliğine inanıyorum. }\end{array}$ & 4,85 & $\begin{array}{l}\text { Kesinlikle } \\
\text { Kattlyorum }\end{array}$ & 4,35 & $\begin{array}{l}\text { Kesinlikle } \\
\text { Katiliyorum }\end{array}$ \\
\hline
\end{tabular}

Tablodaki cümlede kadın ve erkek katılımcılar en çok 'Kesinlikle Katılıyorum' puan aralığına denk düşen seçeneği işaretlemişlerdir. Her iki grup da idarecilerin yetişkin psikoloji ve davranışları ile ilgili eğitimleri almasının kesinlikle gerekli olduğunu düşünürken, iki grup eğitimcinin de bu eğitimlerin olumlu herhangi bir davranış değişikliğine yol açacağını beklememeleri dikkat çekicidir. Davranış değişikliği beklenmemesinin nedeni erkek öğretmenlerin yıldırmaya uğradıklarını düşünmemeleri; kadın öğretmenlerin ise yıldırmaya uğradıklarını, ancak verilecek eğitimin idarecilerin davranışlarında bir değişiklik yaratmaya yetmeyeceğini düşündükleri şeklinde yorumlanabilir.

\section{Sonuç ve Öneriler}

Milli Eğitim Bakanlığı’’na bağlı ilköğretim kurumlarında görev yapan 115’i kadın, 115’i erkek 230 öğretmene 30 maddeden oluşan yıldırma ölçeği ile kişisel bilgi formu uygulandıktan sonra şu sonuçlara ulaşılmıştır.

- İlköğretim kurumlarında yıldırma, daha çok kadın öğretmenlere uygulanmaktadır. Kadınlar cinsiyetleri nedeniyle ayrımcıllğg uğradıklarını düşünmektedirler.

- İlköğretim kurumlarında görev yapan 21-30 yaş arasındaki evli kadın öğretmenler kendileriyle aynı durumda olan diğer erkek ve kadın öğretmenlerden daha fazla yıldırmaya maruz kalmaktadırlar.

- Kadınlar özellikle izin almalarını gerektiren durumlarda yıldırmaya uğradıklarını düşünmektedirler.

- Erkek öğretmenler, idarecilerinin hastalık iznini almalarını zorlaştırmadığını belirtirken; kadın öğretmenler idarecilerinin izin almalarını zorlaştırdığını ifade etmişlerdir.

- Kadın öğretmenler erkek meslektaşlarıyla karşılaştırıldığında yöneticilerinden adil muamele görmediklerini belirtmişlerdir.

- Meslek yılı 1-3 sene arasındaki kadın öğretmenler diğer meslektaşlarına oranla daha fazla yıldırmaya uğramaktadırlar.

- Kurumdaki görev süresi ve meslek yılı arttıkça yıldırmaya maruz kalma algısı azalmaktadır. 
Karabacak Aşır, S., \& Akın, G. (2014). İlköğretim okullarındaki yıldırmaya (mobbing) toplumsal cinsiyet bağlamında bir bakıs.. International Journal of Human Sciences, 11(1), 584-602. doi: 10.14687/ijhs.v11i1.2655

- Katılımcılar, idarecilerinin yetişkin psikolojisi ve davranışları konusunda eğitim almaları gerektiğini düşünmektedirler. Ancak eğitimi alsalar da idarecilerinin davranışlarının değişebileceği bağlamında kararsız kalmışlardır.

Araştırma sonuçları çerçevesinde konuyla ilgili karar vericiler ve araştırmacılar için aşağıdaki öneriler geliştirilebilir:

1- Okullarda idareciler tarafindan öğretmenlere yönelik yıldırmanın önlenmesi için idareci kadroya, yıldırmanın insan psikolojisi ve çalışma verimi üzerindeki etkilerine yönelik hizmet içi eğitimler verilmelidir.

2- İdarecilerle, yıldırma ve gerçekleştirme kanalları ile ilgili olarak farkındalık arttırıcı etkinlikler yapilmalıdır.

3- Eğitimler verilirken toplumsal cinsiyet algısına dikkat çekilerek cinsiyet ayrımcıllğını önleyici içerikli konular ele alınmalıdır.

4- Yildırmanin toplumsal cinsiyet boyutu ele alınarak, toplumsal cinsiyet algisindan kaynaklanan yıldırma ile ilgili farkındalık arttırıcı eğitim programları hazırlanmalıdır.

5- Eğitim etkinliklerinde yetişkin psikolojisi, yetişkin davranışları, etkili iletişim gibi konulara yer verilmelidir.

6- Bu çalışma yıldırmanın idareciler tarafindan uygulanıp uygulanmadı̆̆ı konusunda yapılmıştır. İleriki çalışmalarda, toplumsal cinsiyet değişkeni bağlamında öğretmenlerin kendi aralarında yıldırma davranışı gösterip göstermediğinin incelenmesi alanyazına katkı sağlayacaktır.

\section{Kaynaklar}

Cemaloğlu, N. ve Ertürk, A. (2007). Öğretmenlerin maruz kaldıkları yıldırma eylemlerinin cinsiyet yönünden incelenmesi. Türk Eg̈itim Bilimleri Dergisi, say1 5, cilt 2, s. 345-362.

Cengiz, S. (2010). İlkögretim okulu yöneticilerinin yönetim tarzlarmm ögretmenleri yuldorma düreyine etkisi. Yayınlanmamış Yüksek Lisans Tezi, Sakarya Üni. Sosyal Bilimler Enst., Sakarya.

Connell, R. W. (1998). Toplumsal cinsiyet ve iktidar. Çev: Cem Soydemir, Ayrıntı Yayınları, İstanbul.

Çobanoğlu, S.. (2005). Yildrrma. İsyerinde psikolojïk saldrr ve mücadele yöntemleri. İstanbul Timaş Yayınları.

Davenport, N, Schwartz, R.D. ve Elliott, G.P. (2003).Yuldirma İsyerinde Duygusal Taci‡: Çev: Osman Cem Önertoy, Sistem Yayıncilik, Ankara.

Einarsen, S. (1999). The nature and causes of bullying at work. International Journal of Manpower, Vol. 20(1/2) , pp. 16-27.

Ekiz, Volkan. (2010). İsletmelerde yaşanan psikolojïk şiddet. Yayınlanmamış Yüksek Lisans Tezi, Atılım Üniversitesi Sosyal Bilimler Enstitüsü İşletme Ana Bilim Dalı, Ankara.

Ertürk, A. (2005). Öğretmen ve okul yöneticilerinin okul ortamında maruz kaldıklar yuldirma eylemleri (Ankara ili ilkö̈rretim okullar örneği). Yayımlanmamış Yüksek Lisans Tezi, Gazi Üniversitesi Ĕ̆itim Bilimleri Enstitüsü, Ankara.

Güldü, Ö., Ersoy-Kart, M. (2009). Toplumsal cinsiyet rolleri ve siyasal tutumlar; sosyal psikolojik bir değerlendirme. Ankara Üniversitesi, Siyasal Bilgiler Fakülte Dergisi. htpp// 
Karabacak Aşır, S., \& Akın, G. (2014). İlköğretim okullarındaki yıldırmaya (mobbing) toplumsal cinsiyet bağlamında bir bakış. International Journal of Human Sciences, 11(1), 584-602. doi: 10.14687/ijhs.v11i1.2655

dergiler.ankara.edu.tr/dergiler/42/998/12.144.pdf adresinden 20.05.2013 tarihinde erişilmiş̧tir.

Gökçe, A. T. (2006). İsyerinde yuldırma: Özel ve resmi ilkögrretim okulu ögretmen ve yöneticileri üzerine yapılan bir araştırma. Yayımlanmamış Doktora Tezi, Ankara Üniversitesi, Eğitim Bilimleri Enstitüsü, Ankara.

Kaptan, S. (1993). Bilimsel arastırma ve istatistik teknikleri. Tek Iş1k Ofset, Ankara.

Karabacak Aşır, S. (2011). Mamak balk eğitimi merkez̧inde açılan kurslara katılan kadinlarn eğitime katılma ve terk nedenleri. Yayımlanmamış Doktora Tezi, Ankara Üniversitesi, Eğitim Bilimleri Enstitüsü, Ankara.

Keashly, L. \& Jagatic K. (2003). By another name. American perspectives on workplace bullying. Ed. S. Einarsen, H. Hoel, D. Zapf \& C.L. Cooper. Bullying and Emotional Abuse in the Workplace, London: Taylor \& Francis Group.

Leymann, H. (1996). The content and development of mobbing at work. European Journal of Work and Organizational Psychology, Vol. 5., Issue. 2.

Mimaroğlu Bucuklar, N. (2009). Öğretmenlerin maruz kaldıklar ynldırma eylemlerinin tükenmisslikleri ve bą? değģskeenler ile ilişkisinin incelenmesi. Yayınlanmamış Yüksek Lisans Tezi, Maltepe Üniversitesi, İstanbul.

Ocak, S. (2008). Öğretmenlerin duygusal taciz. (ynldrma)'e iliskin algzlar (Edirne ili örnĕgi). Yayınlanmamış Yüksek Lisans Tezi. Trakya Üniversitesi, Sosyal Bilimler Enstitüsü, Edirne.

Oglesby, C. A., Hill, K. L. (1993). Gender and sport. Handbook of research on sport psychology. Macmillian Publishing Company, New York.

Onbaş, N (2007). İlkögrretim okulu ögretmenlerinin eğitim örgütlerinde duygusal şiddete ilişkin görü̈sleri ü̃erine bir araştırma. Yayınlanmamış Yüksek Lisans Tezi, Sosyal Bilimler Enstitüsü, Harran Üniversitesi, Urfa.

Oxford Advanced Learner's Dictionary. (2005). Oxford University Press.

Ökten, S.. (2009). Gender and power: the system of gender in southeastern anatolia. The Journal of International Social Research, Volume 2, p. 302- 312.

Sankır, H. (2010). Eril tabakküm ve üstün erillik olgusunun plâstik sanatlar alannda toplumsal cinsiyet rollerinin olusumuna etkileri üzerine sosyolojik bir değerlendirme. www.sdergi.hacettepe.edu.tr /hasan_sankir_2_1010.pdf adresinden 15.05.2013 tarihinde erişilmiştir.

Tan, M. (1979). Çocuğun cinsiyetine göre ailenin başariya etkisi. Ankara Üniversitesi Eğitim Bilimleri Fakültesi Dergisi, Cilt 12, say1 1, sayfa 107-125.

Tan, M. (1979). Kadın, ekonomik yașamı ve eğitimi. Türkiye İș Bankası Kültür Yayınları, Ankara.

Tinaz, P. (2006). Isyerinde psikolojik taciz. (ynldrrma). Beta Basım, İstanbul.

Topkaya Sevinç, E. (2011). Mobbing with a gender perspective: how women perceive, experience and are affected from it?. Unpublished Master Thesis, Graduate School of Social Sciences of Middle East Technical University, Ankara.

Tutar, H.(2004). Isyerinde psikolojik siddet. Platin Yayınları, 3. Bask1, Ankara.

Yıldırım, G (2010). Illkögretim okulu sine ögretmenlerinin okul müdürleri tarafindan ynldurma davranıslarna maruz kalma durumları. Kırıkkale İli Örneği. Yayımlanmamış Yüksek Lisans Tezi, Kırıkkale Üniversitesi Sosyal Bilimleri Enstitüsü, Kırıkkale.

Yıldırım, Ş, Şimşek H. (2006). Sosyal bilimlerde nitel araştırma yöntemleri. 6. Baskı, Seçkin Yayınları, Ankara.

Yücetürk, E. (2003). Bilgi çağında örgütlerin görünmeyen yüzü: mobbing (yıldırma). Sendikal Notlar, Say1:26, 2005

www.yok.gov.tr/ulusalteztaramamerkezisonuclari adresinden 25.04.2013 tarihinde erişilmiştir. 
Karabacak Așır, S., \& Akın, G. (2014). İlköğretim okullarındaki yıldırmaya (mobbing) toplumsal cinsiyet bağlamında bir bakış. International Journal of Human Sciences, 11(1), 584-602. doi: 10.14687/ijhs.v11i1.2655

\section{Extended English Abstract}

Introduction: Mobbing is an English concept first used by biologists in the 19th century to describe the behavior of birds flying around the nest to protect the attackers (Tinaz, 2006). Mobbing has always been a case of occurrence since creation of human being; however it wasn't denominated. Onwards of 20th century, the increase in the number of employees and the competition among them have come out as an issue in the workplace a result of the acceleration of industrialization. Thus, employees have abused each other psychologically; powerful and authorized employees have oppressed the weak ones. Turkey has begun to experience the same practices as well and Turkish concepts as 'mobbing' and 'psychological violence' have aroused (Ekiz, 2010). Nevertheless, In Turkey, nor the academia or the business organizations do have enough interest and attention towards the process of mobbing. When the academic studies are examined between the years of 2005-2012, 198 master and doctoral thesis are found on mobbing (www.yok.gov.tr / ulusaltezmerkezitaramasonuclari). Only 48 of these studies are related to the mobbing in educational environment. Among the studies conducted in the field of education are; mobbing practiced by school administrators (Yildirım, 2010), mobbing in respect of management styles of administrators (Cengiz, 2010), teachers' perceptions of mobbing (Ocak, 2008), the views of primary school teachers about emotional violence in educational organizations (Onbaş, 2007), the correlation between the act of mobbing exposed to teachers and their burnout levels (Mimaroğlu Bucuklar, 2009).

Women are expected to accept the rule of men in proportion to patriarchal domination in the context of gender stereotype. This acceptance is based on biological, economic, and religious foundations (Tan, 1979). Being male or female in a social life means to revive the gender role of the person which is determined because of his/her sex. A learning process is required for the implementation of gender role. Expected roles of men and women can vary according to societies. However; it is experienced in any society. This highlights the self-generating and universal dimensions of gender. In addition to the perception of gender, the situational variables such as socio-economic variables, education level, marital status, occupation and also the current political orientation leads to the formation and persistence of gender discrimination (Güldü, Ersoy-Kart, 2009). The table of examples which are aggressive behaviors and mobbing at workplace designed by Keashly ve Jagatic (2003) facilitates the determination of mobbing.

Purpose: The patriarchal paradigm, which determines attitudes and behaviors in all areas of social life, primarily expect women to accept the rule of men. Since systems are constructed to ensure the acceptance of continuity and superiority of men, mobbing can be experienced in every level of workplace. Therefore, the problem of this study is to search whether there is an implementation of mobbing process in the educational institutions in the context of gender implications.

Method and Materials: In this study, descriptive method was used to evaluate teachers' views on mobbing implemented by primary school administrators in the context of gender. In a descriptive model; events, objects, entities, organizations, groups and various fields are tried to be described. These studies are also called as 'survey' and they are conducted on a large number of objects or subjects in a given period of time. Therefore, understanding and grouping both objects and subjects better, determining the relationship between them can be achieved (Kaptan, 1998).

A personal information form to collect demographic data and a questionnaire to determine the scale of mobbing were determined as data collection tools. The first part of the questionnaire was implemented to determine the scale of mobbing which was based on the table designed by Keashly ve Jagatic (2003). The second section of the survey consists of three sentences in which the thoughts of the participants about the necessity of in-service training on adult psychology for school administrators are asked.

Participants: To reach the participants, the snowball technique was used. In snowball technique, existing study subjects recruit future subjects from among their acquaintances. Thus the sample 
Karabacak Aşır, S., \& Akın, G. (2014). İlköğretim okullarındaki yıldırmaya (mobbing) toplumsal cinsiyet bağlamında bir bakiş. International Journal of Human Sciences, 11(1), 584-602. doi: 10.14687/ijhs.v11i1.2655

group appears to grow like a rolling snowball. As the sample builds up, enough data is gathered to be useful for research (Yıldırım\& Şimşek 2006).

\section{Results and Discussion:}

Mobbing in respect of application for taking a day off: According to the results of the research, female teachers feel under psychological violence by their administrators when they apply for a day off. Because female teachers are responsible for the care of their children, when their children get sick, they need to ask for the day off. If it is repeated, it may be a problem for the administrators.

Mobbing in respect of fair treatment: According to the results of the research, male teachers are not sure whether they treated fairly whereas female teachers feel that they are not treated so.

Mobbing in respect of gender: On a similar footing, female and male teachers are treated differently by their administrators. The statement in the questionnaire 'I am discriminated because of my gender' is answered by female teachers as 'Strongly Agree', while it is answered by male teachers as 'Strongly Disagree'.

Mobbing in respect of age: Based on the data obtained from the results of research, female teachers compared to the male teachers at same age range experience mobbing more. Regardless of gender, the younger adults are exposed to mobbing more than the elders.

Mobbing in respect of marital status: According to the results of the research, married female teachers feel that they are exposed to mobbing more than any other groups of teachers.

Mobbing in respect of professional seniority: The female teachers who are experienced from 1 to 3 years feel that they are the ones who are exposed to mobbing most.

Mobbing in respect of tenure at the current school: According to data obtained from the research, female teachers experience mobbing more than male teachers. Besides, the feeling of exposure to mobbing decreases as the tenure increases among female teachers.

In-service training for administrators to stop mobbing: Both female and male teachers believe that their administrators must participate in the in-service trainings; however neither female teachers nor male teachers do anticipate any behavioral change in their administrators.

Conclusion and Recommendations: According to the findings of research, mobbing is applied to female teachers more than male teachers in primary schools. Married female teachers working in primary schools who are between the ages of 21 to 30 are more exposed to mobbing. Female teachers who are experienced between 1 and 3 years are more exposed to mobbing compared to their colleagues. Besides, the mobbing rate decreases as the tenure increases. Participants think that administrators they work with should attend trainings on adult psychology and behaviors, yet they are not sure whether this training can change the behaviors of their administrators. In-service training for administrators about adult psychology including gender issues, further research on mobbing that is practiced by teachers against their colleagues can be given as recommendations. 